\title{
Yolk Utilization in Summer Flounder (Paralichthys dentatus) Embryos and Larvae Reared at Two Temperatures
}

\author{
D. M. Johns and W. H. Howell
}

Environmental Protection Agency, Environmental Research Laboratory, Narragansett, Rhode Island 02882, USA

\begin{abstract}
The influence of rearing temperature on growth and yolk utilization in embryos and larvae of the summer flounder Paralichthys dentatus has been investigated. Rates of development, growth and yolk conversion efficiencies were determined for embryos and larvae reared at $16^{\circ}$ and $21^{\circ} \mathrm{C}$. Larvae reared at $21^{\circ} \mathrm{C}$ completed total yolk absorption sooner than did larvae reared at $16^{\circ} \mathrm{C}$. However, no significant differences were found in total body length, ash-free dry weight or yolk utilization efficiency for larvae from the two groups. The similarity in growth and yolk utilization efficiency for larvae reared at the two temperatures suggests that the physiological mechanisms involved are able to compensate for temperature changes.
\end{abstract}

\section{INTRODUCTION}

Summer flounder Paralichthys dentatus range from Maine to Florida, with the greatest concentration between Cape Cod, Massachusetts and Cape Hatteras, North Carolina (Bigelow and Schroeder, 1953). Adults are found in coastal and estuarine areas during the warmer months of the year and migrate offshore onto the continental shelf during the late fall and winter (Murawski, 1970), at which time spawning occurs (Smith, 1973).

The species supports a large sport fishery (Poole, 1962) and an important commercial fishery. Landings in New York and New Jersey in 1974 totaled nearly six million pounds valued at close to two million US dollars (Anonymous, 1974). In addition to being an important food fish, summer flounder embryos and larvae are being used in a wide variety of laboratory experiments.

Smigielski (1975) successfully induced laboratory spawning employing hormonal stimulation. The ease with which the fish can be spawned and the high viability of the resulting embryos and larvae has led to their use in nutritional bioassays (MacPhee and Howell, unpublished) and experiments on larval mass-rearing techniques (MacPhee, unpublished). The present study was undertaken to: (1) determine the influence of temperature on embryonic and larval development

(C) by Inter-Research and (2) to determine daily energy budgets for these developmental stages.

Similar works detailing temperature effects on developmental rates and yolk utilization efficiencies of larvae have been done with many marine species, including Pacific sardine (Lasker, 1964), herring (Blaxter and Hempel, 1966), sole (Alderdice and Forrester, 1971) and tautog (Laurence, 1973). For pertinent reviews consult 'Marine Ecology', Volume I: Kinne 1970 and Volume III: Kinne, 1977. Studies of this nature have several applications; the most direct of which is their use in establishing environmental conditions for efficient mass culture. In field applications, they can be used as an aid in aging individuals given the development stage at collection time and ambient temperature. Such data also enhance the understanding of factors affecting stock-recruitment relationships (Laurence, 1978).

\section{MATERIALS AND METHODS}

Brood stock adult summer flounder (Paralichthys dentatus) were collected by otter trawl from the west passage of Narragansett Bay, Rhode Island (USA) between June 20 and September 28, 1978. Adults were maintained in the laboratory in 2700-1 tanks supplied 
with raw seawater at ambient temperature, which ranged from $20.0^{\circ} \mathrm{C}$ in August to $13.5^{\circ} \mathrm{C}$ in November, when the last fish were spawned. Adults were periodically fed a diet of live mummichogs Fundulus heteroclitus and Atlantic silversides Menidia menidia. Both sexes were injected intramuscularly 4-5 times weekly with $1.0 \mathrm{mg}$ carp pituitary dissolved in Ringer's solution per kilogram fish wet weight, following the method of Smigielski (1975). Injections were continued until the fish became running ripe. Eggs were stripped into plastic pans and fertilized with a milt-seawater mixture. Fertilized eggs were placed in either 40-1 modified hatching jars or 6-1 plastic pans. After hatching, all larvae were transferred to 6-1 plastic pans.

Developing embryos were incubated at either $16^{\circ}$ or $21^{\circ} \mathrm{C}$. Rearing temperatures were maintained at $16.09^{\circ} \mathrm{C} \pm 0.81 \mathrm{C}^{\circ}$ and $21.0 \mathrm{C}^{\circ} \pm 1.00 \mathrm{C}^{\circ}$ respectively, using two different methods. At $16^{\circ} \mathrm{C}$, plastic pans were placed in seawater tables where the flow rate of ambient seawater was adjusted to maintain temperature. At $21^{\circ} \mathrm{C}$, plastic pans were placed in an Instant Ocean* aquarium equipped with a temperature-regulating circulation bath.

Embryonic and larval stages were determined using the criteria established by Smith and Fahay (1970), who described three developmental phases. Briefly, Phase I encompasses developmental events between fertilization and closure of the blastopore. During this period, the notochord and eye buds become discernible and the embryo extends half way around the yolk. Phase II is considered to be the time between blastopore closure and the time when the embryo bends out of its axial plane. During Phase II, myomeres become visible and pigmentation appears. Phase III encompasses the remainder of development up to hatching. Major events during this phase include continued development of the eyes, increase in myomere number and further pigmentation.

The energy budget of an organism with an endogenous source of energy can be defined by the following equation:

$$
C=P+R+U
$$

where $C$ is the yolk energy consumed, $P$ the portion of energy used for growth, $R$ the portion used for metabolism, and $U$ the portion lost through excretion. For these experiments, daily energy budgets were calculated by the dry weight method presented in detail by Toetz (1966) and Laurence (1969). In general, energy consumed (C) and converted to tissue growth $(P)$ are determined from calculations of the daily changes in their respective weights which are then multiplied by

\footnotetext{
- Reference to tradenames does not imply endorsement by the United States Environmental Protection Agency.
}

their respective joule equivalents to yield daily values of energy used or converted to tissue. The difference between these two values is the energetic cost of metabolism $(R)$ as well as energy lost through excretion (U).

For weight measurements, samples were first rinsed in isotonic $0.9 \%(\mathrm{~W}: \mathrm{V}$ ) ammonium formate, dried at $70{ }^{\circ} \mathrm{C}$ for $24 \mathrm{~h}$, and weighed on a Perkin-Elmer ${ }^{1}$ autobalance to the nearest $1.0 \mu \mathrm{g}$. The samples were then ashed at $500^{\circ} \mathrm{C}$ for at least $8 \mathrm{~h}$ and then reweighed. Ash-free dry weights were determined for a minimum of 10 samples of unfertilized eggs and 10 samples of embryos and larvae daily. The number of embryos and larvae in a sample ranged from 20 to 25 and from 5 to 6 , respectively. Ash free weights of chorions were estimated using chorions that remained after hatching. Care was taken to use only those that appeared whole.

Yolk measurements were taken with an ocular micrometer. Measurements were made at $24 \mathrm{~h}$ intervals beginning with unfertilized eggs and continuing throughout the developmental period to complete yolk absorption. Yolk-sac volume was calculated using volume formulae appropriate for the shape of the yolk. The volume of yolk in unhatched embryos could be measured only once during early development since later staged embryos curved over the yolk mass making accurate measurements impossible. The one yolk measurement made prior to hatching was at $24 \mathrm{~h}$ postfertilization for embryos at $16{ }^{\circ} \mathrm{C}$. The volume $\left(V_{e}\right)$ of the embryo at this time and temperature was that of a spherical segment:

$$
V_{e}=1 / 6 \pi h\left(h^{3}+3 a^{2}\right)
$$

where $h$ is the distance between the highest curved area of the embryo and flattened yolk, and $a$ is the radius at the base of the embryo. The volume of yolk was then estimated by subtracting the embryo volume $\left(V_{e}\right)$ from the total spherical volume of the yolk and embryo combined. The yolk-sac of a hatched larva was eliptical and its volume $\left(V_{y s}\right)$ was calculated from the formula for a prolate spheriod:

$$
V_{y s}=(\pi / 6) L H^{2}
$$

where $L$ is the length and $H$ the height of the yolk sac. Unfertilized eggs were spherical in shape; thus the volume was calculated using the formula for the volume of a sphere.

Total lengths of the larvae were measured from the tip of the snout to the end of the caudal fin fold. Measurements were made with an ocular micrometer.

Ash-free joule equivalents ( $\mathrm{J} / \mathrm{ash}$-free $\mu \mathrm{g}$ ) for yolk and tissue were determined using wet oxidation in the presence of an acid-dichromate mixture (Maciolek, 1962). Unfertilized ova were used to determine energy content of yolk; homogenized samples of larvae after 
total yolk absorption were used to determine the energy content of tissue. It is assumed that the chemical composition of yolk does not change appreciably during larval development (Lasker, 1962) so the energy equivalent obtained from unfertilized ova can be used throughout the development period. It is also assumed that a homogeneous sample of larval tissue provides an average energy equivalent for all tissues produced during larval growth.

Heart beat rates for larvae were determined on a daily basis from hatching until complete yolk-sac absorption. Larvae were placed in 1-2 $\mathrm{ml}$ of temperature-equilibrated $30 \% \mathrm{~S}$ water and observed under a dissecting microscope using low-level dark field illumination. Heart beats were counted for $30 \mathrm{~s}$ with one determination being made per larva.

One-way analysis of variance was used to test for significant differences in length, dry weight and ashfree dry weight between the larvae reared at $16^{\circ}$ and $21^{\circ} \mathrm{C}$.

\section{RESULTS}

\section{Rate of Development}

In an effort to understand the effect of temperature on developmental rate, embryonic stages were observed at 6 -h intervals from fertilization to hatching at $16^{\circ}$ and $21{ }^{\circ} \mathrm{C}$ (Table 1). Embryos held at $16^{\circ} \mathrm{C}$ developed slower than those at $21^{\circ} \mathrm{C}$, with developmental sequences at $16{ }^{\circ} \mathrm{C}$ generally appearing later than at $21^{\circ} \mathrm{C}$. Hatching began at $48 \mathrm{~h}$ post-fertilization at $21{ }^{\circ} \mathrm{C}$, and at $56 \mathrm{~h}$ post-fertilization at $16{ }^{\circ} \mathrm{C}$. Total yolk-sac absorption was complete by $120 \mathrm{~h}$ post-fertilization in larvae reared at $21{ }^{\circ} \mathrm{C}$ while at $16{ }^{\circ} \mathrm{C}$, complete absorption did not occur until $168 \mathrm{~h}$ post-fertilization. Larvae reared at both temperatures appeared to have well-developed functional mouths and guts at the time of complete yolk absorption.

\section{Embryo and Larval Growth and Energetics}

Unfertilized ova of Paralichthys dentatus are spherical in shape with a mean diameter of $1.02 \mathrm{~mm}$ (Table
2). Yolk within the ovum occupies approximately $83.3 \%$ of the egg volume and accounts for $88 \%$ of the dry weight. Egg yolk contains approximately $2.2 \times 10^{4}$ J-g (5318 cal-g).

During development, the amount of yolk decreases as a result of its utilization as an energy source for growth metabolism and maintenance metabolism, as well as its conversion to tissue. An oil droplet in the posterior portion of the yolk-sac is present throughout the yolk-sac period and does appear to diminish in size during yolk absorption. The effect of incubation temperature on yolk utilization rate is presented in Table 3. Yolk reserves decrease during embryo and early larval development (Fig. 1). It can be seen that the rate of yolk utilization is relatively slow just prior to

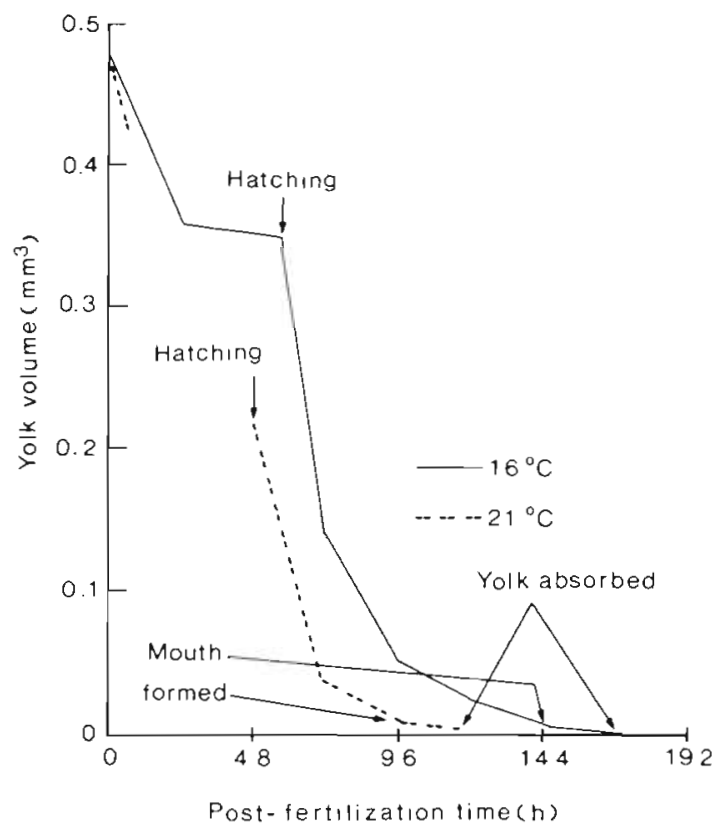

Fig. 1. Paralichthys dentatus. Yolk utilization by embryos and larvae reared at two temperatures

hatching and also in late larval development when the yolk reserves are almost depleted.

Incubation temperature did not have a significant effect on larval growth in length (Table 4). At yolk-sac absorption larvae reared at $16{ }^{\circ} \mathrm{C}$ were slightly longer

Table 1. Paralichthys dentatus. Developmental stages of embryos and larvae reared at $16^{\circ}$ and $21{ }^{\circ} \mathrm{C}$. Stage criteria based on Smith and Fahay $(1970)$

\begin{tabular}{|c|c|c|c|c|c|c|c|c|c|c|c|}
\hline \multirow{4}{*}{ 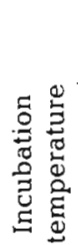 } & & & & & Post-fe & rtilization & time (h) & & & & \\
\hline & & 6 & 12 & 18 & 24 & 30 & 36 & 42 & 48 & 54 & 56 \\
\hline & $16{ }^{\circ} \mathrm{C}$ & $\begin{array}{l}\text { Very early } \\
\text { Phase I }\end{array}$ & $\begin{array}{c}\text { Early } \\
\text { Phase I }\end{array}$ & $\begin{array}{l}\text { Early to mid } \\
\text { Phase I }\end{array}$ & $\begin{array}{c}\text { Mid } \\
\text { Phase I }\end{array}$ & $\begin{array}{c}\text { Late } \\
\text { Phase I }\end{array}$ & Phase II & $\begin{array}{c}\text { Early } \\
\text { Phase III }\end{array}$ & $\begin{array}{c}\text { Mid } \\
\text { Phase III }\end{array}$ & $\begin{array}{c}\text { Late } \\
\text { Phase III }\end{array}$ & Hatch \\
\hline & $21^{\circ} \mathrm{C}$ & $\begin{array}{c}\text { Early } \\
\text { Phase I }\end{array}$ & $\begin{array}{c}\text { Mid } \\
\text { Phase I }\end{array}$ & $\begin{array}{c}\text { Mid to late } \\
\text { Phase I }\end{array}$ & $\begin{array}{c}\text { Late } \\
\text { Phase I }\end{array}$ & $\begin{array}{c}\text { Late } \\
\text { Phase II }\end{array}$ & $\begin{array}{c}\text { Early } \\
\text { Phase III }\end{array}$ & $\begin{array}{c}\text { Late } \\
\text { Phase III }\end{array}$ & Hatch & & \\
\hline
\end{tabular}


Table 2. Paralichthys dentatus. Summary of data on unfertilized ova. (n): sample size. All values are means \pm one standard deviation. Values resulting from mathematical calculation do not have a sample size determination

\begin{tabular}{|lccccccccc}
\hline Material & $\begin{array}{c}\text { Diameter } \\
(\mathrm{mm})\end{array}$ & $(\mathrm{n})$ & $\begin{array}{c}\text { Dry wt } \\
(\mu \mathrm{g})\end{array}$ & $(\mathrm{n})$ & $\%$ Ash & $(\mathrm{n})$ & $\begin{array}{c}\text { Volume } \\
\left(\mathrm{mm}^{3}\right)\end{array}$ & $\begin{array}{c}\text { Energy content } \\
\left(\mathrm{Jg}^{-1}\right)\end{array}$ \\
\hline Ova & $1.02 \pm 0.10$ & $(99)$ & $40.90 \pm 2.18$ & $(80)$ & $9.20 \pm 0.92$ & $(10)$ & $0.57 \pm 0.20$ & $2.2 \times 10^{4} \pm 2 \times 10^{3}$ & $(9)$ \\
$\begin{array}{l}\text { Yolk } \\
\text { within ova }\end{array}$ & $0.96 \pm 0.08$ & $(99)$ & $35.92 \pm 1.80$ & $(10)$ & $8.70 \pm 0.53$ & $0.47 \pm 0.15$ & $1.96 \times 10^{4}$ \\
Chorion & - & & $4.98 \pm 0.25$ & $(3)$ & $12.80 \pm 8.3$ & (3) & - & $2.67 \times 10^{3} \pm 2.47 \times 10^{2}$ \\
\hline
\end{tabular}

Table 3. Paralichthys dentatus. Changes in yolk volume and yolk ash-free weight for embryos and larvae reared at $16^{\circ}$ and $21^{\circ} \mathrm{C}$. Values are means \pm one standard deviation. $\mathrm{NM}=$ not measurable. $(\mathrm{n})$ : sample size

\begin{tabular}{|c|c|c|c|c|c|c|}
\hline $\begin{array}{l}\text { Temp. } \\
\left({ }^{\circ} \mathrm{C}\right)\end{array}$ & $\begin{array}{c}\text { Post-fertilization } \\
\text { time }(\mathrm{h})\end{array}$ & $\begin{array}{l}\text { Yolk volume } \\
\qquad\left(\mathrm{mm}^{3}\right)\end{array}$ & $(\mathrm{n})$ & $\begin{array}{l}\text { Yolk ash-free dry wt } \\
(\mu \mathrm{g})\end{array}$ & (n) & $\%$ loss from initial volume \\
\hline 16 & Unfertilized & $0.474 \pm 0.153$ & (99) & $32.78 \pm 0.12$ & $(10)$ & - \\
\hline 21 & Unfertilized & $0.474 \pm 0.153$ & (99) & $32.78 \pm 0.12$ & (10) & - \\
\hline 16 & 24 & $0.361 \pm 0.041$ & $(30)$ & $25.00 \pm 0.15$ & $(10)$ & 23.8 \\
\hline 21 & 24 & NM & & NM & & NM \\
\hline 16 & 56 & $0.348 \pm 0.057$ & $(40)$ & $24.07 \pm 0.06$ & $(10)$ & 26.5 \\
\hline 21 & 48 & $0.219 \pm 0.093$ & $(40)$ & $16.54 \pm 0.12$ & (10) & 53.7 \\
\hline 16 & 72 & $0.142 \pm 0.042$ & $(40)$ & $9.82 \pm 0.01$ & $(10)$ & 70.1 \\
\hline 21 & 72 & $0.034 \pm 0.015$ & (40) & $2.57 \pm 0.08$ & (10) & 92.8 \\
\hline 16 & 96 & $0.049 \pm 0.018$ & $(40)$ & $3.38 \pm 0.06$ & $(10)$ & 89.7 \\
\hline 21 & 96 & $0.004 \pm 0.001$ & $(40)$ & $0.30 \pm 0.05$ & (10) & 99.2 \\
\hline 16 & 120 & $0.023 \pm 0.011$ & $(40)$ & $1.58 \pm 0.05$ & (10) & 95.2 \\
\hline 21 & 120 & $0.000 \pm 0.000$ & (40) & $0.00 \pm 0.00$ & (10) & 100 \\
\hline 16 & 144 & $0.005 \pm 0.002$ & $(40)$ & $0.37 \pm 0.023$ & $(10)$ & 98.9 \\
\hline 21 & - & & & & & - \\
\hline 16 & 168 & $0.000 \pm 0.000$ & $(40)$ & $0.00 \pm 0.00$ & $(10)$ & 100 \\
\hline 21 & - & & & & & - \\
\hline
\end{tabular}

Table 4. Paralichthys dentatus. Changes in length and dry weight during early development of larvae reared at $16^{\circ}$ and $21^{\circ} \mathrm{C}$. (n): sample size. Values are means \pm one standard deviation. Values resulting from mathematical calculation do not have a sample size determination. $\mathrm{NM}=$ not measurable

\begin{tabular}{|c|c|c|c|c|c|c|c|c|c|}
\hline $\begin{array}{l}\text { Temp. } \\
\left({ }^{\circ} \mathrm{C}\right)\end{array}$ & $\begin{array}{l}\text { Post-fertilization } \\
\text { time (h) }\end{array}$ & $\begin{array}{l}\text { Larval length } \\
\qquad(\mathrm{mm})\end{array}$ & $(\mathrm{n})$ & $\begin{array}{l}\text { Larva } \\
\text { dry }\end{array}$ & $\begin{array}{l}\text { tissue } \\
\text { vt }(\mu \mathrm{g})\end{array}$ & $\{n\}$ & $\%$ ash & (n) & $\begin{array}{l}\text { Larval tissue } \\
\text { ash-free dry wt }(\mu \mathrm{g})\end{array}$ \\
\hline 16 & Unfertilized & 0 & & \multicolumn{3}{|c|}{0} & 0 & & 0 \\
\hline 21 & Unfertilized & 0 & & \multicolumn{3}{|c|}{0} & 0 & & 0 \\
\hline 16 & 24 & NM & & \multirow{2}{*}{\multicolumn{2}{|c|}{$\begin{array}{c}0.362 \pm 0.02 \\
\text { NM }\end{array}$}} & (10) & $8.7 \pm 0.9$ & $(10)$ & 0.36 \\
\hline 21 & 24 & NM & & & & & $\mathrm{NM}$ & & $N M$ \\
\hline 16 & 56 & $2.85 \pm 0.18$ & $(40)$ & 2.70 & \pm 0.07 & $(10)$ & $10.9 \pm 0.8$ & $(10)$ & 1.83 \\
\hline 21 & 48 & $2.82 \pm 0.14$ & $(40)$ & 10.00 & \pm 0.47 & (10) & $16.0 \pm 0.7$ & (10) & 7.08 \\
\hline 16 & 72 & $3.38 \pm 0.22$ & $(40)$ & 17.91 & \pm 0.09 & (10) & $12.5 \pm 1.5$ & $(10)$ & 15.26 \\
\hline 21 & 72 & $3.53 \pm 0.13$ & (40) & 24.55 & \pm 0.80 & (10) & $16.5 \pm 1.8$ & (10) & 20.28 \\
\hline 16 & 96 & $3.52 \pm 0.19$ & $(40)$ & 24.76 & \pm 0.53 & $(10)$ & $15.1 \pm 1.9$ & (10) & 20.78 \\
\hline 21 & 96 & $3.64 \pm 0.12$ & (40) & 25.09 & \pm 0.55 & (10) & $17.0 \pm 2.1$ & (10) & 20.79 \\
\hline 16 & 120 & $3.61 \pm 0.17$ & $(40)$ & 24.52 & \pm 0.54 & (10) & $15.5 \pm 0.9$ & (9) & 20.56 \\
\hline 21 & 120 & $3.87 \pm 0.10$ & (40) & 26.78 & \pm 0.27 & (10) & $20.0 \pm 1.3$ & (10) & 21.42 \\
\hline 16 & 144 & $3.72 \pm 0.25$ & $(40)$ & 25.40 & \pm 0.27 & $(10)$ & $16.0 \pm 1.2$ & (10) & 20.96 \\
\hline 21 & - & - & & & - & & - & & - \\
\hline 16 & 168 & $3.89 \pm 0.09$ & $(40)$ & 24.78 & \pm 1.18 & (10) & $16.0 \pm 1.5$ & (9) & 20.81 \\
\hline 21 & - & - & & & - & & - & & - \\
\hline
\end{tabular}


Table 5. Paralichthys dentatus. Caloric content and yolk utilization efficiency for embryos and larvae reared at $16^{\circ}$ and $21^{\circ} \mathrm{C}$. Bracketed numbers: sample size. Values resulting from mathematical calculation do not have a sample size determination

\begin{tabular}{|c|c|c|c|c|}
\hline $\begin{array}{l}\text { Temp. } \\
\left({ }^{\circ} \mathrm{C}\right)\end{array}$ & $\begin{array}{c}\text { Post-fertilization } \\
\text { time }(\mathrm{h})\end{array}$ & $\begin{array}{c}\text { Energy content of yolk }\left(\mathrm{J} \mu \mathrm{g}^{-1}\right) \\
\left.\text { [Yolk ash-free dry wt } \times 0.02226 \mathrm{~J} \mu \mathrm{g}^{-1}\right]\end{array}$ & $\begin{array}{c}\text { Energy content of a larva }\left(\mathrm{J}_{\mu \mathrm{g}}^{-1}\right) \\
{\left[\text { Larva ash-free dry wt } \times 0.0216 \mathrm{~J}^{-1} \mathrm{~g}^{-1}\right]}\end{array}$ & $\begin{array}{l}\text { Yolk utilization } \\
\text { efficiency }\end{array}$ \\
\hline 16 & Unfertilized & $0.729 \pm 0.067$ & - & - \\
\hline 21 & Unfertilized & $0.729 \pm 0.067$ & - & - \\
\hline 16 & 24 & 0.557 & 0.008 & 4.9 \\
\hline 21 & 24 & - & - & - \\
\hline 16 & 56 & 0.536 & 0.038 & 19.6 \\
\hline 21 & 47 & 0.368 & 0.151 & 42.0 \\
\hline 16 & 72 & 0.218 & 0.330 & 92.0 \\
\hline 21 & 72 & 0.059 & 0.435 & 79.0 \\
\hline 16 & 96 & 0.075 & 0.448 & 82.4 \\
\hline 21 & 96 & 0.008 & 0.446 & 17.1 \\
\hline 16 & 120 & 0.033 & 0.446 & 0.0 \\
\hline 21 & 120 & 0.000 & $0.452 \pm 0.021$ & 100.0 \\
\hline 16 & 144 & 0.008 & 0.452 & 33.2 \\
\hline 21 & - & - & - & - \\
\hline 16 & 168 & 0.000 & $0.452 \pm 0.019$ & 0.0 \\
\hline 21 & - & - & - & - \\
\hline
\end{tabular}

than those reared at $21^{\circ} \mathrm{C}$, but the difference was not significant $(\mathrm{P}>0.05)$.

At the time of yolk-sac absorption, dry weights were significantly greater $(\mathrm{P} \leq 0.05)$ in larvae reared at $21{ }^{\circ} \mathrm{C}$; however this difference appears to be attributable to a greater ash content (Table 4). When weights

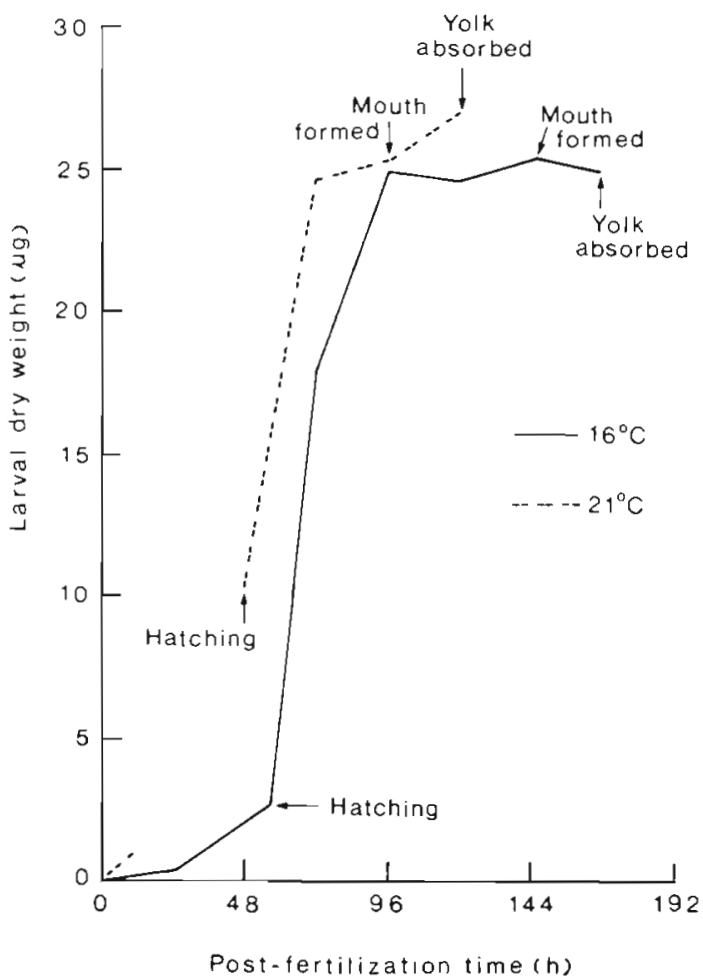

Fig. 2. Paralichthys dentatus. Growth of embryos and larvae reared at two temperatures were adjusted to reflect only the organic constituents (ash-free dry weight) no significant difference was found between the two groups $(P>0.05)$.

The pattern of weight increase during development was similar for the two groups (Fig. 2). At $16^{\circ} \mathrm{C}$, larvae gained close to their maximum weight by $96 \mathrm{~h}$ post fertilization after which time the weight remained relatively stable. For larvae reared at $21^{\circ} \mathrm{C}$, the weight gain was continuous throughout the yolk-sac period with no plateau in weight gain observed.

Embryos and larvae reared at both $16^{\circ}$ and $21{ }^{\circ} \mathrm{C}$ utilized $0.729 \mathrm{~J}$ larva ${ }^{-1}$ during development. Of this, $0.276 \mathrm{~J}$ ( $0.066 \mathrm{cal}) \mathrm{larva}^{-1}$ were expended for catabolic requirements. The remaining fraction was converted to larval tissue. This represents an overall yolk utilization efficiency of $62 \%$. Temperature appeared to have little or no effect on yolk utilization efficiency; however, day-to-day yolk usages for the two temperatures were different (Table 5). At $16{ }^{\circ} \mathrm{C}$, yolk utilization efficiency was high up to 120 hours post fertilization, then dropped to near $0 \%$ for the remaining 48 hours. For larvae reared at $21{ }^{\circ} \mathrm{C}$, yolk utilization efficiency was relatively high throughout development.

Heart beat rates for larvae reared at $21{ }^{\circ} \mathrm{C}$ were consistently higher than in larvae reared at $16{ }^{\circ} \mathrm{C}$ (Table 6). $Q_{10}$ value for the entire yolk-sac period (all data within a temperature group combined) was 1.96 .

\section{DISCUSSION}

Smith (1973) estimated that eggs of Paralichthys dentatus developing at $9.1{ }^{\circ} \mathrm{C}$ would require $142 \mathrm{~h}$ to 
Table 6. Paralichthys dentatus. Heart beat rates of larvae reared at $16^{\circ}$ and $21^{\circ} \mathrm{C}$. Bracketed numbers: sample size. Values are means \pm one standard deviation

\begin{tabular}{|c|c|c|c|c|c|c|c|c|c|c|c|c|}
\hline \multirow{4}{*}{ 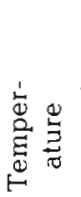 } & & \multirow{2}{*}{\multicolumn{2}{|c|}{56}} & \multirow{2}{*}{\multicolumn{6}{|c|}{$\begin{array}{l}\text { Post-fertilization time (h) } \\
96\end{array}$}} & \multirow{2}{*}{\multicolumn{2}{|c|}{144}} & \multirow[b]{2}{*}{168} \\
\hline & & & & & & & & & & & & \\
\hline & $16{ }^{\circ} \mathrm{C}$ & $92 \pm 13$ & (20) & $84 \pm 14$ & (25) & $91 \pm 16$ & (20) & $104 \pm 11$ & (20) & $117 \pm 8$ & (19) & $134 \pm 8 \quad(20)$ \\
\hline & $21^{\circ} \mathrm{C}$ & $128 \pm 7$ & (19) & $117 \pm 6$ & (20) & $153 \pm 15$ & (19) & $210 \pm 20$ & (20) & & & \\
\hline
\end{tabular}

hatch, while only $56 \mathrm{~h}$ would be needed at $22.9^{\circ} \mathrm{C}$. These estimates were based on values for laboratoryhatched eggs in which the incubation temperature dropped from $18.3^{\circ}$ to $15.5^{\circ} \mathrm{C}$ during the development period (Smith and Fahay, 1970). In another study, summer flounder eggs incubated at temperatures ranging from $15^{\circ}$ to $18^{\circ} \mathrm{C}$ required 72 to $96 \mathrm{~h}$ to hatch (Smigielski, 1975). Laurence (personal communication), working with well-defined temperatures has found that larvae will hatch in $72 \mathrm{~h}$ when reared at both $22^{\circ}$ and $24^{\circ} \mathrm{C}$ while $126 \mathrm{~h}$ is required at $16^{\circ} \mathrm{C}$.

Incubation times presented here are shorter than previous estimates. Working with a fairly constant temperature $\left( \pm 1.0 \mathrm{C}^{\circ}\right)$, we found that the incubation time at $21^{\circ} \mathrm{C}$ was some $8 \mathrm{~h}$ shorter than estimated for a similar temperature $\left(22.9^{\circ} \mathrm{C}\right)$. At $16^{\circ} \mathrm{C}$, the observed incubation time of $56 \mathrm{~h}$ was much shorter than the 72 to 96 h reported by Smigielski (1975) using a similar temperature interval $\left(15^{\circ}-18^{\circ} \mathrm{C}\right)$. The reasons for such discrepancies in incubation times at various temperatures are unclear. Undoubtedly, the fluctuating temperature regimes used by Smith and Fahay (1970) and Smigielski (1975) prolonged the development period, although other abiotic factors could account for some of the differences. For example, dissolved oxygen content, which was not determined in any of the studies, has been shown to alter development times by as much as $31 \%$ (Garside, 1966).

Our data indicate that yolk utilization and growth are not different in summer flounder larvae reared at the temperatures investigated. This suggests that either the two temperatures were too close to result in significantly different effects or the physiological mechanisms involved in yolk utilization and growth in this species are independent of temperature (or at least the mechanisms are able to compensate for temperature changes). The fact that temperature reduced hatching and development times suggests that temperature is indeed affecting the biological processes occurring during development.

Wood (1932) reported temperature independence in yolk utilization efficiency for trout embryos when incubated at $3^{\circ}, 7^{\circ}, 10^{\circ}$, and $12^{\circ} \mathrm{C}$. The data for $10^{\circ} \mathrm{C}$ was not Wood's original work, but was calculated by him from work by Gray (1926). Marr (1966) however, dis- counted Wood's conclusion of thermal independence after recalculating Gray's data and finding that the yolk utilization efficiency at $10^{\circ} \mathrm{C}$ is actually higher than that calculated by Wood. Subsequent experiments (Fig. 3) have shown that a wide variety of yolk utilization efficiency patterns are possible. Although none of these patterns indicate temperature independence in yolk utilization, data for Salmo salar (Hayes and Pelluet, 1945), Clupea harengus (Blaxter and Hempel, 1966) and Tautoga onitis (Laurence, 1973) embryos and larvae exhibited efficiency patterns over a part of their temperature range that are similar to our pattern. The relative stability of utilization efficiency over these temperature ranges is probably due to the interrelationship of two processes (Blaxter and Hempel, 1966). They are: (1) the rate of rise in metabolic requirements over the temperature range and (2) the reduction in development time with increasing tempe-

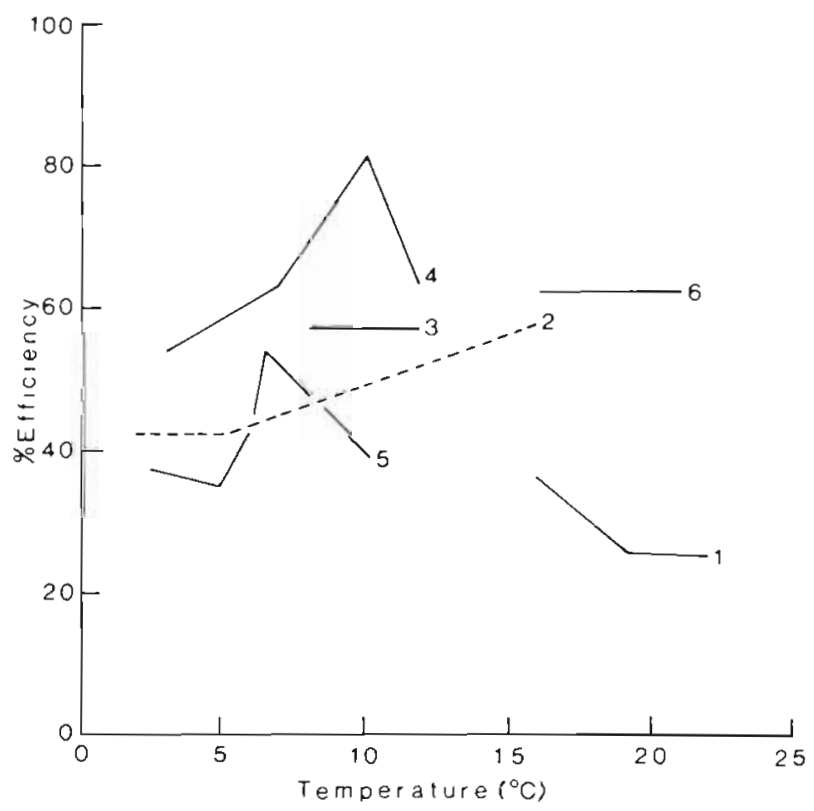

Fig. 3. Effects of temperature on yolk utilization efficiency during embryonic and larval development of various fishes. (1) Laurence, 1973; (2) Hayes and Pelluet, 1945; (3) Blaxter and Hempel, 1976 - includes all data, both large and small eggs; (4) Marr, 1966; (5) Ryland and Nichols, 1967; (6) present study 
ratures. If these two processes change at the same rate (i. e. exhibit similar $Q_{10}$ values), then the yolk utilization efficiency will remain unchanged. The $Q_{10}$ values for both heart beat rate $\left(Q_{10}=1.96\right)$ and development rate (reciprocal of development time; $Q_{10}=2.14$ ) are similar in summer flounder larvae, indicating a constancy in the ratio of yolk needed for metabolism relative to yolk converted to tissue. Such a constancy results in equal yolk utilization efficiencies at the different temperatures.

Our data suggest that equal-sized larvae can be produced at either $16^{\circ}$ or $21^{\circ} \mathrm{C}$; hence, rigid temperature control over the early life history is not required. Early larval survival is also not significantly different at these two temperatures (MacPhee, unpublished). Determination of optimum rearing conditions, however, would have to include a more rigorous investigation on the effects of temperature, since there could be a temperature at which a higher yolk utilization efficiency would be found.

Laboratory studies on yolk utilization have been largely aimed at investigating one aspect of the 'critical period' concept in the early life history stages of fish. This concept was originated by Hjort (1914) and has since undergone extensive review (Hjort, 1926; Marr, 1956; May, 1974). Causes of the very high mortality during this period may include environmental stress, relationships with other organisms (competitors, predators, disease agents), developmental abnormalities, and nutrition deficiency between the time yolk-sac reserves are exhausted and feeding is initiated (Toetz, 1966). The appearance of an energy deficit prior to functional feeding abilities has been observed by Lasker (1962) in the Pacific sardine. Such a deficit would lead to starvation if the ability to feed did not soon develop. Other workers were not able to detect an energy deficit prior to active feeding (Gray, 1926; Smith, 1947, Toetz, 1966; Laurence, 1969, 1973; Eldridge et al., 1977). Our data add to the evidence that starvation due to the exhaustion of endogenous energy reserves coupled with the physical inability to feed may not be one of the major causes of mortality during the 'critical period'. Although there is little evidence for an energy deficit prior to the initiation of feeding, one cannot deny that larger larvae produced by the most efficient use of endogenous energy would presumably have better foraging and escape abilities than would a smaller larva (Ahlstrom, 1954; Ryland, 1963; Laurence, 1973). The survivorship of larger larvae would be higher, thus providing the potential basis for a stronger year-class.

Acknowledgements. We wish to thank Dr. G. Klein-MacPhee for providing us with summer flounder eggs and for her many timely and lengthy discussions on rearing fluke. We would also like to thank Drs G. C. Laurence, S. B. Saila, W. H. Krueger, H. P. Jefferies, as well as Mr. A. Beck and Mr. D. Bengtson for their critical review of the manuscript.

\section{LITERATURE CITED}

Ahlstrom, E. H. (1954). Distribution and abundance of egg and larval populations of the Pacific sardine. Fish. Bull. Fish Wildl. Serv. U.S. 93: 83-140

Alderdice, D. F., Forrester, C. R. (1971). Effects of salinity and temperature on embryonic development of the petrale sole Eopsetta jordani. J. Fish. Res. Bd Can. 28: 727-744

Anonymous (1974). U.S. Dept. Commerce, NOAA, NMFS. Fish statistics of the U.S., Stat. Digest No. 68

Bigelow, H. B., Schroeder, W. C. (1953). Fishes of the gulf of Maine. Fish. Bull. Fish Widl. Serv. U.S. 53: 1-577

Blaxter, J. H. S., Hempel, G. (1966). Utilization of yolk by herring larvae. J. mar, biol. Ass. U. K. 46: 219-234

Eldridge, M. B., Echeverria, T., Whipple, J. A. (1977) Energetics of Pacific herring (Clupea harengus pallasi) embryos and larvae exposed to low concentrations of benzene, a monoaromatic component of crude oil. Trans. Am. Fish. Soc. 106: 452-461

Garside, E. T. (1966). Effects of oxygen in relation to temperature on the development of embryos of brook trout. J. Fish. Res. Bd Can. 23: 1121-1134

Gray, J. (1926). The growth of fish. I. The relationship between embryos and yolk in Salmo fario. J. exp. Biol. 4: $215-225$

Hayes, F. R., Pelluet, D. (1945). The effect of temperature on the growth and efficiency of yolk conversion in the salmon embryo. Can J. Res. D23: 7-15

Hjort, J. (1914). Fluctuations in the great fisheries of northern Europe viewed in the light of biological research. Cons. Perm. Int. Explor. Mar, Rapp et Proc. Verb 20: 1-228

Hjort, J. (1926). Fluctuations in the year classes of important food fishes. J. Cons. perm. int. Explor. Mer 1: 5-38

Kinne, O. (ed.) (1970). Marine ecology, Vol. I, Environmental factors, Part 1. Wiley, London

Kinne, O. (1977). Cultivation of animals: research cultivation. In: Kinne, O. (ed.) Marine ecology, Vol. III, Cultivation, Part 2. Wiley, Chichester, pp. 579-1287

Lasker, R. (1962). Efficiency and rate of yolk utilization by developing embryos and larvae of the Pacific sardine, Sardinops caerulea (Girard). J. Fish. Res. Bd Can. 19: $867-875$

Lasker, R. (1964). An experimental study on the effect of temperature on the incubation time, development, and growth of Pacific sardine embryos and larvae. Copeia 1964 (2): 399-405

Laurence, G. C. (1969). The energy expenditure of largemouth bass larvae, Micropterus salmoides, during yolk absorption. Trans. Am. Fish. Soc. 98: 398-404

Laurence, G. C. (1973). Influence of temperature on energy utilization of embryonic and prolarval tautog, Tautoga onitis. J. Fish. Res. Bd Can. 30: 435-442

Laurence, G. C. (1978). Comparative growth, respiration and delayed feeding abilities of larval cod (Gadus morhua) and haddock (Melanogrammus aeglefinus) as influenced by temperature during laboratory studies. Mar. Biol. 50 $1-7$

Maciolek, J. (1962). Limnological organic analysis by quantitative dichromate oxidation. Fish. Res. Rep. 60: 1-61 
Marr, D. H. A. (1956). The 'critical period' in the early life history of marine fishes. J. Cons. perm. int. Explor. Mer 21: $160-170$

Marr, D. H. A. (1966). Influence of temperature on the efficiency of growth of salmonid embryos. Nature, Lond. 212: 957-959

May, R. C. (1974). Larval mortality in marine fishes and the critical period concept. In: Blaxter, J. H. S. (ed.) The early life history of fish. Springer-Verlag, New York, pp. 3-19

Murawski, W. (1970). Results of tagging experiments of summer founder, Paralichtys dentatus conducted in New Jersey waters from 1960 to 1967. N. J. Dept Environ. Protect., Misc. Rep. 5M: 1-72

Poole, J. C. (1962). The fluke population of Great South Bay in relation to the sport fishery. Fish Game J. N.Y. 9: 93-117

Ryland, J. S. (1963). The swimming speeds of plaice larvae. J. exp. Biol. 4: 285-299

Ryland, J. S., Nichols, J. H. (1976). Effect of temperatures on the efficiency of growth of plaice pro larvae. Nature, Lond. 214: $529-530$
Smigielski, A. S. (1975). Hormone-induced spawnings of the summer flounder and rearing of the larvae in the laboratory. Progve Fish Cult. 37: 3-8

Smith, S. (1947). Studies in the development of the rainbow trout (Salmo irideus). I. The heat production and nitrogenous excretion. J. exp. Biol. 23: 57-373

Smith, W. G. (1973). The distribution of summer flounder, Paralichthys dentatus, eggs and larvae on the continental shelf between Cape Cod and Cape Lookout, 1965-66. Fish Bull. Fish Wildl. Serv. U.S. 71: 527-535

Smith, W. G., Fahay, M. P. (1970). Description of eggs and larvae of the summer flounder, Paralichthys dentatus. Res. Rep. U.S. Fish. Wildl. Serv. 75: 1-21

Toetz, D. W. (1966). The changes from endogenous to exogenous sources of energy in bluegill sunfish larvae. Invest Indiana Lakes Streams 1: 115-146

Wood, A. H. (1932). The effect of temperature on the growth and respiration of fish embryos (Salmo fario). J. exp. Biol. 9: $271-276$

This paper was presented by Professor J. Vernberg; it was accepted for printing on December 18, 1979. 